\title{
GROWTH OF FOUR FAST GROWING TREE SPECIES ON TAILINGS MEDIA FROM GOLD MINING COMPANY PT ANTAM UBPE PONGKOR
}

\author{
Ulfah J. Siregar and Wirrahma
}

Dept. Silviculture, Fac. Forestry, Bogor Agricultural University, IPB

\begin{abstract}
Tailing from mining activity contains heavy metal that can be managed by phytoremediation. Plant selection to be used in phytoremediation plays important role that determine the success of these activities. The objective of this research is to study the growth of four forest tree species in media containing tailings from gold mining. Four fast growing tree species, i.e. Swietenia macrophylla King., Anthocephalus macrophyllus (Roxb.) Havil., Maesopsis eminii Engl., and Toona sureni (Blume) Merr., and two kinds of growing media, i.e. tailings and mixture of tailings + compost with 3:1 ratio, were used in a Completely Randomized Factorial Design. The growth parameters measured were plant height and diameter, leaf length and width, number of leaves, stomata density, total wet and dry biomass, also root-shoot ratio, and percentage of survival. The results of the research showed that plant types significantly affect all parameters observed. Media treatment had significant effect on total wet and dry biomass only. Interaction between plant types and media gave significant effect only on total wet biomass. Based on survival and growth parameter observed A. macrophyllus gave best performance.
\end{abstract}

Key words: A. macrophyllus, M. eminii, phytoremediation, S. macrophylla, tailings, T. sureni

\section{INTRODUCTION}

Indonesia has rich natural resources for national development, which is utilized for maximum benefit of people, while keeping sustainability in mind. Various mining activities in Indonesia continuously progress since long time ago and inevitably destroy the forest and the environment at large. Thus rehabilitation of the exmining area is urgently needed in order to restore the condition of the forest as it once was.

One kind of waste that potentially harms the environment is waste that categorized as called B3 (Bahan Beracun Berbahaya) in Indonesian language, meaning Hazardous Poisonous Substances, of which among them is heavy metal. Example of heavy metal which have a bad impact on the environment is $\mathrm{Cu}, \mathrm{Fe}$, $\mathrm{Hg}, \mathrm{Mn}, \mathrm{Pb}$ and $\mathrm{Zn}$. Activities like gold and coal mining will generate B3 waste containing the heavy metals that could contaminate and pollute the environment. Polluted environment should be remediated immediately before undergoes further degradation.

One of the gold mining company that hass been operational since 1970 is PT Antam UBPE Pongkor, in Bogor, West Java. From the mining activities PT Antam has produced tailing waste, which contains many dangerous substances that can be toxic to living things. One effort to manage tailing mud is application of phytoremediation. Phytoremediation is activity that use plants and/or microorganisms to degrade, absorb or retard contaminants in soil and/or ground water to become harmless for living organism. Ideally the plant used in phytoremediation is a hyperaccumulator that can grow and accumulate heavy metals at high concentration in its tissues.
Four fast growing tree species, i.e. Swietenia macrophylla King., Anthocephalus macrophyllus (Roxb.) Havil, Maesopsis eminii Engl., and Toona sureni (Blume) Merr. is often used in an attempt to revegetate deforested area in Indonesia, but have not yet known their ability to absorb heavy metal. Therefore, this research was done to find out the ability of those forest plants to grow on the tailing ground as well as absorb the heavy metals to the extent of hyperaccumulator. The objective of this research is to study the growth of four forest tree species, i.e. Swietenia macrophylla King., Anthocephalus macrophyllus (Roxb.) Havil., Maesopsis eminii Engl., and Toona sureni (Blume) Merr. in media containing tailings from gold mining.

\section{METHODS}

The research was done in the greenhouse of the Department of Silviculture, Faculty of Forestry IPB, and observation on stomata was done at laboratory of Department of Agronomy and Horticulture, Faculty of Agriculture IPB.

Source of tailing mud came from PT Antam, UBPE Pongkor, Bogor, Indonesia while compost was from Dramaga Permanent Nursery. Media consisted of two types, i.e.1200 g tailing (A1) and a mixture of $900 \mathrm{~g}$ tailing and $300 \mathrm{~g}$ compost (A2) were put in polybags. The seedlings purchased from Dramaga Permanent Nursery were S. macrophylla (T1), A. Macrophyllus (T2), M. Eminii (T3), and T. Sureni (T4) aged 3 months, having similar height and diameter for each species. Transplanting process of seedlings into the media took place in either morning or afternoon to minimize 
transpiration rate. Watering was done as necessary to keep optimum level of moisture in the media.

Growth parameters were measured for 4 months, including plant height and diameter, leaf length and width, number of leaves, stomata density, total wet and dry biomass, root-shoot ratio, and percentage of survival.

This research employed factorial design with 2 factors, i.e. plant species as first factor, which was consisted of 4 species, and media as second factor, which consisted of 2 types. There were totally 8 treatments, replicated 3 times, and each replication there were 10 units of plant, which made a total of 240 experimental units. The model for experimental design was:

$$
Y i j k=\mu+\alpha i+\beta j+(\alpha \beta) i j+\varepsilon i j k
$$

Analysis of variance used $\mathrm{F}$ test with following hypothesis:

a. P-value $>\alpha(0.05)$, the treatment doesn't give significant effect on the parameters.

b. $\mathrm{P}$-value $<\alpha(0.05)$ the treatment give significant effect on the parameters observed

When the effect is significant, the analysis continued with Duncan multiple range test. All data were recorded in Excell and analyzed using software SAS 9.1.3

\section{RESULT AND DISCUSSION}

Table 1 shows results of ANOVA of two treatments on all parameters measured. Plant types significantly affected plant height and diameter, leaf length and width, total wet and dry biomass, and root-shoot ratio. Media significantly affected total wet and dry biomass, while interaction between plant types and media gave significant effect only on total wet biomass.

Table 1 Effects of media and plant types on the growth of seedlings for four months

\begin{tabular}{lccc}
\hline Parameters & \multicolumn{3}{c}{ P values } \\
\cline { 2 - 4 } & Plant types & Media & $\begin{array}{c}\text { Plant types }+ \\
\text { media }\end{array}$ \\
\hline Height & $0.0001^{* *}$ & $0.9388 \mathrm{~ns}$ & $0.0571 \mathrm{~ns}$ \\
Diameter & $0.0001^{* *}$ & $0.0980 \mathrm{~ns}$ & $0.3128 \mathrm{~ns}$ \\
Leaf length & $0.0001^{* *}$ & $0.1913 \mathrm{~ns}$ & $0.3284 \mathrm{~ns}$ \\
Leaf width & $0.0001^{* *}$ & $0.9793 \mathrm{~ns}$ & $0.2367 \mathrm{~ns}$ \\
WB & $0.0001^{* *}$ & $0.0048^{* *}$ & $0.0046^{* *}$ \\
DB & $0.0001^{* *}$ & $0.0393^{*}$ & $0.0807 \mathrm{~ns}$ \\
R/S & $0.0002^{* *}$ & $0.1891 \mathrm{~ns}$ & $0.7476 \mathrm{~ns}$ \\
\hline
\end{tabular}

Note: $\mathrm{WB}=$ total wet biomass, $\mathrm{DB}=$ total dry biomass, $\mathrm{R} / \mathrm{S}=$ root-shoot ratio; $* *=$ highly significant with $\mathrm{p}$ value $<0.01 ; *=$ significant with $\mathrm{p}$-value $<0.05$; $\mathrm{ns}=$ non significant.

As shown in Table $2 M$. eminii seedlings had significantly highest height growth compared to other species. Among four plant species studied, it is well known that $S$. macrophylla has slow growth habit, while the other three species are fast growing ones. Although M. eminii has highest plant height increment, the highest increment in diameter appeared in A. macrophyllus.

Growth indicators of a plant growth can be seen from the number of leaves, leaf length and width. Different plant species significantly affected leaf length and width (Table 2). Leaf length and width ratio, which represents the leaf shape of certain plant species however, unlikely change during the course of plant growth. As shown in Table 4, S. macrophylla has longest leaf length with moderate width; $T$. sureni on the contrary has widest leaf width with moderate length, while $M$. eminii has smallest leaf shape among others.

Table 2 Average height, diameter, leaf length and width of the four plant species studied, growing for 4 months

\begin{tabular}{lcccc}
\hline \multicolumn{1}{c}{ Treatment } & $\begin{array}{c}\text { Height } \\
(\mathrm{cm})\end{array}$ & $\begin{array}{c}\text { Diameter } \\
(\mathrm{mm})\end{array}$ & $\begin{array}{c}\text { Leaf } \\
\text { length } \\
(\mathrm{cm})\end{array}$ & $\begin{array}{c}\text { Leaf } \\
\text { width } \\
(\mathrm{cm})\end{array}$ \\
\hline T3 (M. eminii) & $18.47 \mathrm{a}$ & $1.25 \mathrm{~b}$ & $0.61 \mathrm{c}$ & $0.18 \mathrm{c}$ \\
T2 (A. macrophyllus) & $15.34 \mathrm{~b}$ & $2.22 \mathrm{a}$ & $2.36 \mathrm{~b}$ & $1.66 \mathrm{~b}$ \\
T4 (T. sureni) & $13.88 \mathrm{c}$ & $1.14 \mathrm{~b}$ & $2.89 \mathrm{~b}$ & $2.84 \mathrm{a}$ \\
T1 (S. macrophylla) & $8.98 \mathrm{~d}$ & $1.19 \mathrm{~b}$ & $5.69 \mathrm{a}$ & $1.82 \mathrm{~b}$ \\
\hline
\end{tabular}

Note: different letter in the same column indicates significantly different at $\mathrm{p}$-value $<0.01$.

Generally number of leaves increased as the seedlings grew (Figure 1). Different treatment combination gave different number, even decreased after $5^{\text {th }}$ week. This was due to occurrence of falling leaves.

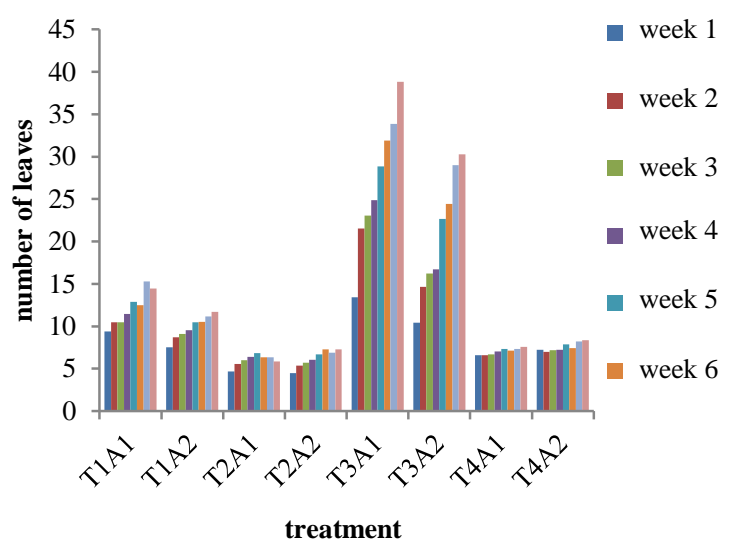

Figure 1 Diagram on the number of leaves for each treatment combination.

Note: $\mathrm{A} 1=$ tailing; $\mathrm{A} 2=$ tailing+compost $; \mathrm{T} 1=S$. macrophylla; $\mathrm{T} 2=$ A. Macrophyllus; $\mathrm{T} 3=M$. eminii; T4 = T. Sureni .

Figure 1 shows that treatment T3A1 (M. eminii on $1200 \mathrm{~g}$ tailing) had highest and steady increase in the the number of leaves compared to others. Some combination showed fluctuative response, i.e. treatment 
T4A1 (T. sureni on $1200 \mathrm{~g}$ tailing) and T4A2 (T. sureni on mix media). On treatment T2A1 (A. macrophyllus on $1200 \mathrm{~g}$ tailing) had decreased number of leaves due to wilted leaves.

Table 3 Stomata density from four species grown in different media

\begin{tabular}{lccc}
\hline \multirow{2}{*}{ Treatment } & \multicolumn{3}{c}{ Stomata density $\left(\right.$ stomata $\left./ \mathrm{mm}^{2}\right)$} \\
\cline { 2 - 4 } & Control & $\begin{array}{c}\text { Tailing } \\
\text { Media }\end{array}$ & $\begin{array}{c}\text { Mix } \\
\text { Media }\end{array}$ \\
\hline $\begin{array}{l}\text { T1 }(\text { S. } \\
\text { macrophylla })\end{array}$ & 254.8 & 366.9 & 351.6 \\
T2 (A. & 285.4 & 356.7 & 331.2 \\
macrophyllus $)$ & & & \\
T3 (M. eminii) & 147.8 & 351.6 & 270.1 \\
T4 (T. sureni) & 152.9 & 203.8 & 198.7
\end{tabular}

Note: Control is a plant that is planted on the soil without treatment

Stomata density depends on the number of stomata in a certain area of leaf, and related to water stress (Sciutti and Morini 1995). According to Hidayat (2009) in Tambaru (2012) stomatal density could be categorized as low ( $<300$ stomata/ $\left.\mathrm{mm}^{2}\right)$, medium (300500 stomata $\left./ \mathrm{mm}^{2}\right)$, and high $\left(>500\right.$ stomata $\left./ \mathrm{mm}^{2}\right)$. Observation on stomata density is presented in Table 4.

Table 3 shows that in general all 4 plant species studied had low to medium stomata density. Stomata density of each plant species was highest in tailing media than control and the mix one. S. macrophylla had highest density, i.e. 366.9 stomata/mm2 planted on tailing media and on average of all media compared to other species. Average lowest number of stomata belonged to T. Sureni. According to Malia (2006) in Hidayati (2009) the higher the number of stomata density, the higher is the potential to heavy metal absorption or air particles.

Table 4 shows that combination of T2A1 (A. macrophyllus on $1200 \mathrm{~g}$ tailing) gave the best response on total wet biomass which was $29.013 \mathrm{~g}$. All plant types had higher total wet biomass on tailing media than mix media, except T4 (T. sureni) which was opposite. Dry biomass usually serves as measure for plant growth. Drying is done to eliminate water in the plants tissue that the weight obtained is the weight of the entire network that is formed from the process of plants metabolism. Dry biomass shows synthesized materials such as polysacharide and lignin in the cell wall and cytoplasm components such as protein, lipid, and amino acid (Salisbury and Ross 1991). A. macrophyllus had highest of both average wet and dry biomass compared to other species studied, indicating best adaptation to the media used. The lowest biomass was $S$. macrophylla.

Table 5 The result of Duncan test effect plant types and media to total dry biomass for 4 months

\begin{tabular}{lcc}
\hline Treatment & $\begin{array}{l}\text { Wet } \\
\text { Biomass }(\mathrm{g})\end{array}$ & $\begin{array}{l}\text { Dry Biomass } \\
(\mathrm{g})\end{array}$ \\
\hline $\mathrm{A} 1$ (tailing $1200 \mathrm{~g})$ & $22.967 \mathrm{a}$ & $10.663 \mathrm{a}$ \\
$\mathrm{A} 2$ (tailing 900 $\mathrm{g}+$ & $20.507 \mathrm{a}$ & $9.777 \mathrm{a}$ \\
compost 300 g) & & \\
\hline Note: different letter in the same column indicates \\
significantly different at p-value $<0.05$.
\end{tabular}

Table 5 show that although media gave significant effect of both wet and dry biomass (Table 1), Duncan test showed there was no difference on both parameters. In general tailing media gave better plant growth compared to mix media as shown by greater wet and dry biomass obtained.

Shoot-root ratio is greatly affected by the amount and type of cells or tissue that formed during growth (Pujawati 2006). Table 6 shows results of shoot-root ratio ranges from Duncan test ranking.

Table 6 Average of root-shoot ratio of each plant species grown for 4 months

\begin{tabular}{ll}
\hline Treatment & Shoot-root Ratio \\
\hline T2 (A. macrophyllus) & $2.740 \mathrm{a}$ \\
T1 S. macrophylla $)$ & $2.463 \mathrm{a}$ \\
T3 M. eminii) & $2.297 \mathrm{a}$ \\
T4 (T. sureni) & $1.623 \mathrm{~b}$
\end{tabular}

Note: different letter in the same column indicates significantly different at $\mathrm{p}$-value $<0.05$.

Three species, i.e A. macrophyllus, S. macrophylla, and $M$. eminii gave similar better response than $T$. Sureni, indicating better adaptation on media treatments. Shoot-root ratio could serve as an indicator to determine media fertility (Frianto 2007 in Winata 2014).

Survival percentages from the first month up to four months were given in Table 7. Most plant species could survive and grow well in the media studied.

S. macrophylla (T1) showed decreasing trend in survival starting on the $3^{\text {rd }}$ month, while $M$. eminii decrease slightly on the same time. This observation might indicate less ability of those plants to grow on tailing contained media.

Table 4 Wet and dry biomass of four types of seedlings on two different media grown for 4 months

\begin{tabular}{ll|l|ll}
\hline Treatment & WB $(\mathrm{g})$ & Treatment & WB $(\mathrm{g})$ & $\mathrm{DB}(\mathrm{g})$ \\
\hline T2A1 & $29.013 \mathrm{a}$ & T2 (A. macrophyllus $)$ & $26.377 \mathrm{a}$ & $12.103 \mathrm{a}$ \\
T2A2 & $23.740 \mathrm{~b}$ & & & \\
T4A2 & $23.630 \mathrm{~b}$ & T4 $($ T. sureni $)$ & $22.050 \mathrm{~b}$ & $10.637 \mathrm{~b}$ \\
T3A1 & $22.973 \mathrm{~b}$ & & $21.090 \mathrm{~b}$ & $9.380 \mathrm{c}$ \\
T4A1 & $20.467 \mathrm{bc}$ & T3 $($ M. eminii $)$ & & \\
T1A1 & $19.410 \mathrm{c}$ & & $17.437 \mathrm{c}$ & $8.770 \mathrm{c}$ \\
T3A2 & $19.200 \mathrm{c}$ & T1 $($ S. macrophylla $)$ & & \\
T1A2 & $15.460 \mathrm{~d}$ & & & \\
\hline
\end{tabular}

Note: $\mathrm{WB}=$ wet biomass; $\mathrm{DB}=$ dry biomass; $\mathrm{A} 1=$ tailing; $\mathrm{A} 2=$ tailing+compost; $\mathrm{T} 1=$ S. macrophylla T2 = A. macrophyllus; $\mathrm{T} 3=M$. eminii; $\mathrm{T} 4=T$. suren ; different letter in the same column indicates significantly different at $\mathrm{p}$-value $<0.05$. 
Table 7 Recapitulation the results percentage of survival for 4 months

\begin{tabular}{lllllll}
\hline \multirow{2}{*}{ Treatment } & Amount & \multicolumn{5}{c}{ Percentage of survival (\%) } \\
\cline { 2 - 6 } & & 0 BST & 1 BST & 2 BST & 3 BST & 4 BST \\
\hline T1A1 & 30 & 100 & 100 & 100 & 86.67 & 73.33 \\
T1A2 & 30 & 100 & 100 & 100 & 86.67 & 76.67 \\
T2A1 & 30 & 100 & 100 & 100 & 100 & 100 \\
T2A2 & 30 & 100 & 100 & 100 & 100 & 100 \\
T3A1 & 30 & 100 & 100 & 100 & 96.67 & 96.67 \\
T3A2 & 30 & 100 & 100 & 100 & 100 & 100 \\
T4A1 & 30 & 100 & 100 & 100 & 100 & 100 \\
T4A2 & 30 & 100 & 100 & 100 & 100 & 100 \\
\hline
\end{tabular}

\section{CONCLUSION}

Plant types gave highly significant effect on growth when they planted on media containing tailing. Growth media had significant effect only on total wet and dry biomass and interaction between plant types and media gave significant effect only on total wet biomass. Based on survival and growth parameter observed $A$. macrophyllus gave best performance on media containing tailing.

\section{REFERENCES}

Hidayati SR. 2009. Analisis kandungan stomata, kadar klorofil dan kandungan logam berat paa daun pohon pelindung jalan kawasan lumpur porong Sidoarjo [skripsi]. Malang (ID): Universitas Islam Negeri Malang.

Pujawati ED. 2006. Pertumbuhan eceng gondok (Eichornia crassipes Mart.Solm) pada air bekas penambangn batubara. Jurnal Hutan Tropis Borneo. No 18: 94-103.

Salisbury BF, Ross CW. 1991. Fisiologi Tumbuhan Jilid I. Bandung (ID): Institut Teknologi Bandung.

Sciutti R, Morini S. 1995. Water-loss and photosynthesis of plum plantlets is influenced by relative-humidity during rooting in-vitro. J. Hortic. Sci. Biotech. 70 (2): 221-228.

Tambaru E. 2012. Potensi absorpsi karbondioksida pada beberapa jenis pohon hutan kota di Kota Makassar [disertasi]. Makassar (ID): Unversitas Hasanuddin Makassar.

Winata B. 2014. Pertumbuhan semai jabon (Anthocephalus cadamba) pada media bekas tambang pasir dengan penambahan sub soil dan arang tempurung kelapa [skripsi]. Bogor (ID) : Institut Pertanian Bogor. 